\title{
Editorial
}

\section{Successful pathways}

\section{Trajetórias de sucesso}

A scientific research only ends its pathway when it is reported to other scientists and physicians, preferably after being reviewed and published. The popular saying "publish or perish" worths to be considered. In other words, a non-published paper is very likely to disappear!

Scientific journals have the role to harbor such researches and help communication among scientists and health professionals. But they also must be easily found and read so that results and scientific methods are transmitted.

An isolated journal hardly will communicate a breakthrough no matter how important it may be. For this reason, scientific journals seek to be admitted in indexing databases or at journals' collections that are popular and known by the scientific and medical community. Such services bring a positive cycle because highly accessed journals draw the investigators' attention bringing as a result good researches, increasing readership and visits.

In 1997 a project was created that aimed to give more visibility to Brazilian scientific production in electronic format.
This project, called Scientific Electronic Library Online (SciELO), resulted from a partnership between the São Paulo Research Foundation (FAPESP) and the Latin American and Caribbean Center on Health Sciences (Bireme) ${ }^{(1)}$. Lastly, in 2002 , the project became supported by the National Council for Scientific and Technological Development (CNPq).

SciELO includes in its electronic collection only scientific journals that have regular periodicity, open accessible content and evaluate contributions by a peer review system. This electronic collection started with 10 Brazilian journals in 1998 and nowadays has 271 national journals and other publications from other countries, mainly Iberoamericans ${ }^{(2)}$.

SciELO had a huge impact in spreading Brazilian scientific journals. For example, in 2009 about 9 million articles were downloaded monthly from it, and the impact factor of journals indexed by SciELO comprising 1997 and 2008 had a mean increase of more than $200 \%{ }^{(3)}$. That is, the initial aim to increase the journals' visibility is effectively being achieved. 
In the last evaluation meeting of December 6, 2011 einstein was added to SciELO electronic library, which constituted a step forward to disclose researches published in our journal. In 10 years of uninterrupted circulation, our journal proved to have the quality required to be part of such selected group of serial titles recognized by the national scientific community, represented by SciELO.

Our journal, einstein has received articles from all the Brazilian territory and also from international contributors, keeping a good flow of production, presenting rejection rates of approximately $50 \%$. Undoubtedly, the inclusion at SciELO will enlarge the journal's flow of articles, reinforcing the idea that building and keeping an institutional open access scientific journal from a private and nonprofitable Institution is viable and beneficial.

Claudio Schvarstman Vice-President of Sociedade Beneficente Israelita Brasileira Albert Einstein

Sidney Glina Editor-in-Chief

\section{REFERENCES}

1. Meneghini R. Avaliação da produção científica e o Projeto SciELO. Ci Inf (Brasília). 1998;27(2);219-20

2. Scielo: Scientific Library Online [Internet]. [citado 2012 Jan 28].Disponível em: http://www.scielo.br/scielo

3. Packer A. Impacto global do SciELO [Internet]. [citado 2012 Fev 12]. Disponível em: http://www.revistapesquisa.fapesp.br20/08/2009 